Vedecký príspevok/ Scientific Article

Recenzované/ Review: 08. 06. 2021

https://doi.org/10.24040/eas.2021.22.1.116-136

\title{
Úloha potenciálu mesta pri budovaní značky mesta
}

\section{The role of the city's potential in city branding}

\section{Jana Matejčíková, Darina Rojíková}

Abstract: Based on a theoretical overview, the paper defines the relationship between the city brand and the city's potential. The aim of the paper is to identify the role and extent of using the potential in branding of selected European and Slovak cities. The results of the Anholt Ipsos Brand City Index and Resonance World's Best Cities rankings were used to analyze the use of potential in branding of 14 European cities. For the needs of analysis of the potential in branding of 8 Slovak regional cities, new rankings were used, based on 24 key factors that people consider most important when choosing a place to live, visit, do business and invest. The results of the analysis confirm the assumption that the recognizability of the city as a brand is higher in cities with better potential. The conclusion of the article summarizes the results of the research and points out the possibilities of city branding, especially in Slovak cities.

Key words: City branding. City potential. City brand. City.

JEL Classification: $\mathrm{O} 20$.

\section{Úvod}

V súčasnej dobe, charakteristickej narastajúcou konkurenciou na trhu území, sa stala značka, jedným $\mathrm{z}$ najdôležitejších prvkov diferenciácie a rozpoznávania miest. Rozpoznatel'nost' mesta ako značky, však ovplyvňuje množstvo faktorov, ktoré sú vzájomne prepojené a navzájom sa dopĺn̆ajú. Pre budovanie úspešnej značky mesta je nevyhnutné tieto vzt'ahy poznat' a následne ich vediet' v správny čas cielene a systematicky riadit', čo je úlohou manažmentu mesta. Autori ako napr. Anholt (2007a, 2014), Kavaratzis (2008, 2010), Baker (2019) a d’alší tvrdia, že úspešná značka mesta musí byt' pravdivá a musí presne odrážat' autentickost' a potenciál mesta. Preto ak majú mestá záujem o posilnenie značky, musia sa v prvom rade zamerat' na zlepšenie reality a to prostredníctvom budovania a zlepšovania potenciálu svojho územia. 
V článku preto vychádzame z predpokladu, že rozpoznatel'nost' mesta ako značky je vyššia pri mestách s lepším potenciálom. Hlavnou myšlienkou článku je identifikovat' úlohu a mieru využívania potenciálu pri budovaní značky vybraných európskych a slovenských miest. Článok je rozdelený na tri kapitoly. Prvá čast' článku teoreticky vymedzuje vzt’ah medzi značkou mesta a potenciálom mesta. Druhá čast’ článku definuje metodiku výskumu, metódy skúmania a údaje použité pri výskume. Tretia čast’ článku prezentuje výsledky analýzy úlohy a miery využívania potenciálu pri budovaní značky vybraných európskych a slovenských miest s využitím výsledkov rankingov Anholt Ipsos Brand City Index a Resonance World's Best Cities, hodnotiacich značky a potenciál európskych miest a nami vytvorených rankingov pre hodnotenie značky a potenciálu slovenských miest, založených na 24 kl’účových faktoroch, ktoré považujú l’udia za najdôležitejšie pri výbere miesta na život, návštevu, podnikanie a investovanie. Na záver práce sumarizujeme výsledky výskumu a poukazujeme na možnosti využívania potenciálu pri budovaní značky, najmä slovenských miest.

\section{Vzt'ah medzi značkou mesta, potenciálom mesta a d'alšími faktormi ovplyvňujúcimi rozpoznatel'nost' mesta ako značky}

Odborníci ako napr. Anholt (2007b), Vela (2013), Eshuis et al. (2014), Baker (2019) a d'alší sa zhodujú na tom, že neexistuje jednotne akceptovaná definícia a prístup k značke mesta a jej budovaniu. Dôvodom pomerne vel'kého množstva rôznych definícií a prístupov k značke mesta je rôznorodost' funkcií, ktoré značka mesta plní a jej multidisciplinárny charakter, ktorý si vyžaduje poznatky z mnohých disciplín ako verejná politika, ekonómia, urbanizmus, geografia, cestovný ruch, marketing, sociológia, psychológia a i.

Autori, ako napr. Foret (2006); Anholt (2007a); Dinnie (2009); Govers, Go (2009), Zenker (2011); Mueller a Schade (2012); Dinnie (2015) a Matlovičová (2015) sa však zhodujú na tom, že značka mesta vychádza z jeho identity, ktorá je tvorená množstvom súborov hmotných a nehmotných prvkov a charakteristík územia existujúcich v rámci určitého sociálno - kultúrneho prostredia, ako sú história, kultúra, mýty a povesti, práva, životný štýl, architektúra, jedlo, hudba, jazyk a i., ktoré sú jedinečné a môžu poskytovat' územiu isté výhody v porovnaní s inými konkurenčnými územiami.

Identita mesta je zároveň viazaná na l’udí, ktorí sú jej nositel'mi a ktorí prostredníctvom nej identifikujú samých seba v zmysle hrdosti a spolupatričnosti s konkrétnym územím. Identita mesta hovorí o tom, čím je mesto z pohl'adu vysielatel’a (Florek, 2011; Kerr, Oliver, 2015).

Podl'a Siweka (2011) a Chromého et al. (2014) je identita mesta premenlivá v čase, nakol'ko vychádza z potenciálu mesta (obrázok 1), ktorý predstavuje možnosti daného mesta 
vynikat' v určitej oblasti a upútat' pozornost' zákazníkov mesta. Vaňová et al. (2017) potenciálom mesta rozumejú: štruktúru, charakteristiky, hodnoty prvkov materiálneho a nemateriálneho prostredia (prírodné prostredie), l'udský faktor (obyvatel'stvo žijúce na území mesta, jeho prejavy a pod.), hodnoty vytvorené l’ud'mi a abstraktné charakteristiky mesta. Podl'a Vaňovej et al. (2017) je každé mesto charakteristické špecifickým prírodno-geografickým, sociodemografickým, socioekonomickým, urbanistickým a inovačným potenciálom.

Odborníci (Anholt, 2007a, 2014; Kavaratzis, 2008, 2010; Baker, 2019 a iní) sa zhodujú v tom, že úspešná značka mesta musí byt' pravdivá a musí presne odrážat' autentickú osobnost' a potenciál mesta. Anholt (2014) d’alej vo svojich prácach zdôrazňuje, že ak majú mestá záujem o posilnenie značky, musia sa v prvom rade zamerat' na zlepšenie reality a to prostredníctvom neustáleho zlepšovania potenciálu svojho územia.

Potenciál mesta je výrazne formovaný vplyvmi vonkajšieho prostredia (politickými, ekonomickými, legislatívnymi, sociálnymi, ekologickými, kultúrnymi, technologickými, demografickými a trendami vo svete). Z tohto pohl'adu má pri formovaní potenciálu mesta, identity mesta a následne aj značky mesta významnú úlohu práve verejná politika, ktorá by mala vytvorit' vhodné podmienky pre ochranu, zachovanie a revitalizáciu kultúrneho, historického a prírodného dedičstva, pre realizáciu významných kultúrnych, športových a spoločenských podujatí, pre budovanie kvalitnej sociálnej, technickej a dopravnej infraštruktúry a v neposlednom rade pre rozvoj a uplatnenie l’udského potenciálu, ktorým mestá disponujú. Na formovaní potenciálu mesta sa významným spôsobom podiel’a tiež manažment mesta, a to spôsobom a kvalitou jeho riadenia.

Pre potreby tvorby a manažovania značky mesta na trhu je nevyhnutné vytvorit’ potenciál mesta, ktorý predstavuje základ pre identitu mesta, následne vybrat' a zredukovat' vel'ké množstvo prvkov identity mesta do menšieho počtu zástupných kategórií prvkov, ktoré budú predstavovat' identitu značky mesta. Takto definovaný teoretický rámec predpokladá existenciu celého radu prvkov identity mesta, ktoré nie sú súčast’ou identity značky mesta. Napriek tomu, že tieto skryté prvky identity mesta nevystupujú ako súčast' identity značky mesta a nie sú teda predmetom marketingovej komunikácie značky (najmä tie atribúty, ktoré spadajú do negatívneho spektra hodnotení), zohrávajú dôležitú úlohu pri formovaní imidžu mesta a jeho značky. Identita značky mesta hovorí o tom, čím je značka z pohladu jej vysielatel’a (Matlovičová, 2015).

Podl'a autorov Kotler et al. (1993); Tapachai, Waryszak, (2000); Beerli, Josefa (2004); Vaňová (2006); Frantál (2007); Govers, Go (2009); Ashworth et al. (2015) je imidž mesta mentálny portrét, resp. prototyp mesta, ktorý vzniká na základe jeho návštevy a predstavuje 
syntézu vnímania daného miesta, zahŕňa rôzne postoje, preferencie, hodnotenia a vzt'ah k územiu. Imidž mesta hovorí o tom, ako je mesto vnímané jeho spotrebitel'mi.

Z uvedených teoretických východísk je zrejmé, že značka mesta je prvkom, ktorý prepája identitu mesta s jeho imidžom (prostredníctvom identity značky mesta a imidžu značky mesta), pričom identita mesta predchádza imidžu mesta (obrázok 1). Manažment mesta by mal preto v prvom rade vytvorit’ víziu identity mesta (vychádzajúc z potenciálu územia), ktorú pretaví do identity značky a zváži, ako ju bude komunikovat' smerom k spotrebitel'om. Komunikované prvky identity značky mesta sú predmetom vnímania u prijímatel'ov a následne pretvárané do podoby imidžu značky mesta. Z uvedeného vyplýva, že imidž značky mesta je zjednodušenou formou imidžu mesta a hovorí o tom, ako je značka mesta vnímaná spotrebitel'mi.

Autori ako napr. Kavaratzis (2008, 2010), Braun et al. (2014), Cavia et al. 2018, Baker (2019) a d’alší tvrdia, že mestá komunikujú svoju značku tromi spôsobmi. Prvý spôsob komunikácie súvisí s fyzickými prvkami a aktivitami mesta, ktoré zahŕňajú architektúru, dizajn mesta, infraštruktúru, ale aj správanie sa mesta, napr. mestskými inštitúciami a obyvatel'mi. Tento spôsob komunikácie značky mesta označujú autori, ako primárna resp. fyzická komunikácia a do vel'kej miery súvisí práve s potenciálom, ktorým mesto disponuje.

Druhý spôsob komunikácie zahŕn̆a formálnu komunikáciu prostredníctvom rôznych tradičných, a moderných foriem marketingovej komunikácie. Označovaná je tiež ako sekundárna komunikácia značky mesta.

Tretí spôsob komunikácie - terciárna komunikácia sa týka ústneho podania informácií o meste prostredníctvom spotrebitel'ov mesta (obyvatel’ov, podnikatel’ov, návštevníkov a i.) a vychádza $\mathrm{z}$ ich osobných skúseností $\mathrm{s}$ mestom. Terciárna komunikácia je neriadeným spôsobom komunikácie, nakol'ko je vo vel'kej miere mimo kontroly manažmentu územia. Terciárna komunikácia ovplyvňuje primárne imidž mesta, ktorý následne ovplyvňuje značku mesta. Tento typ komunikácie môže prinášat' vel'ké výhody, ale aj spôsobovat' pomerne vel'a problémov. Problém s týmto typom komunikácie nastáva hlavne vtedy, ak majú spotrebitelia mesta s mestom negatívne skúsenosti. Je preto dôležité dostat’ tento spôsob komunikácie aspoň pod čiastočnú kontrolu mesta, a to napríklad aj prostredníctvom sociálnych médií. Vzt'ahy medzi jednotlivými faktormi, ovplyvňujúcimi rozpoznatel'nost' mesta, ako značky, z ktorých sme v článku vychádzali, sú zobrazené na obrázku 1. 


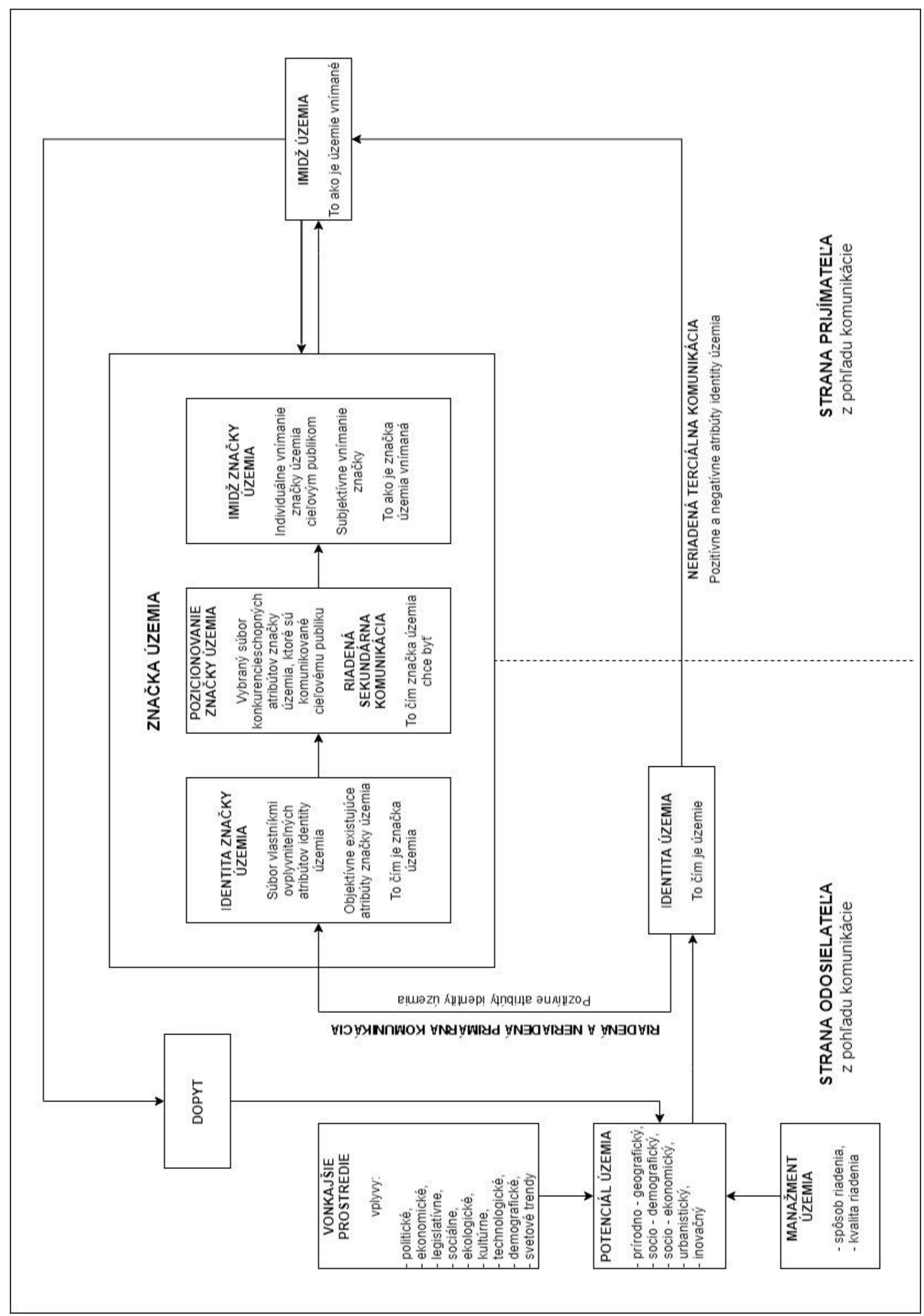

Obrázok 1 Teoretický rámec značky územia

Zdroj: Rojíková, 2021 na základe Kavaratzis (2008), Matlovičová (2015), Vaňová et al. (2017) 


\subsection{Meranie a hodnotenie potenciálu a značky mesta}

V skutočnosti sú značky miest vel'mi zložité, nakol'ko pozostávajú z vel'kého množstva rôznych prvkov, ktoré je možné zaradit' do všeobecnejších kategórií na základe klúčových dimenzií (Zenker, 2011). Kl'účovou však stále zostáva otázka, ktoré prvky identity mesta (vychádzajúc z potenciálu mesta) je potrebné vybrat’ k vytvoreniu a následne meraniu a hodnoteniu značky tak, aby bola pokrytá celá šírka možných atribútov územia?

Pre definovanie klúčových kategórií prvkov sa pre potreby nášho výskumu, v článku podrobnejšie zameriame na metodiku rankingu Anholt - Ipsos City Brand Index, hodnotiaceho značky miest a metodiku rankingu Resonance World's Best Cities, hodnotiaceho potenciál miest.

Prístup spoločností Ipsos a Resonance Consultancy k tvorbe rankingov je založený na 24 kl'účových faktoroch (obrázok 2), ktoré považujú l’udia za najdôležitejšie pri výbere miesta na život, návštevu, podnikanie a investovanie. Výskum týkajúci sa identifikácie faktorov realizovala spoločnost' Ipsos v roku 2018 na vzorke 1000 l’udí žijúcich v USA.

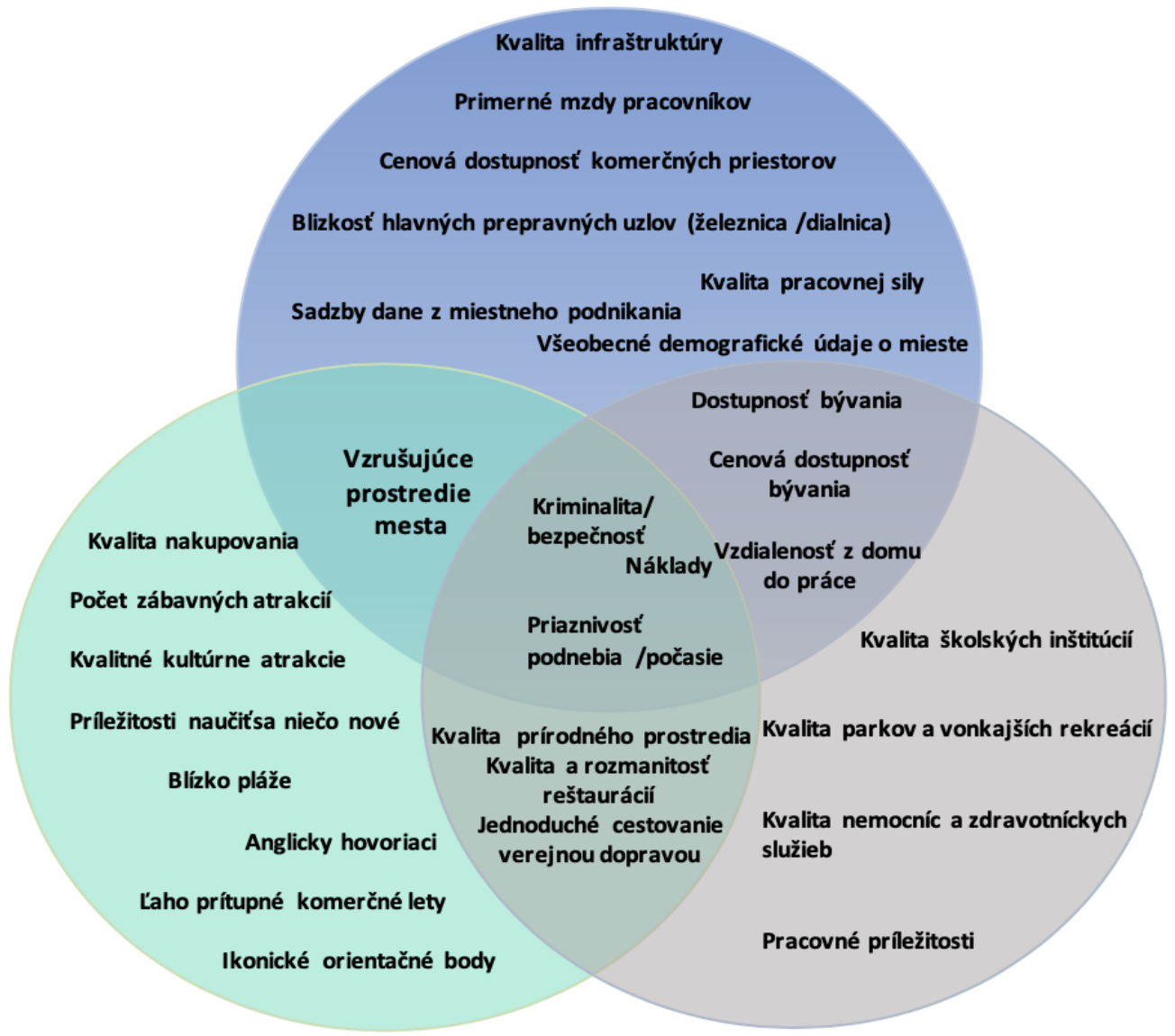

Obrázok 2 Klúčové faktory pri výbere miesta na život, návštevu, podnikanie a investovanie Zdroj: Vlastné spracovanie na základe Ipsos (2018) 
The Anholt - Ipsos City Brand Index (do roku 2016 The Anholt - GfK Roper City Brands Index TM) od roku 2006 hodnotí s periodicitou každé dva roky percepciu 50 miest sveta. Obsahové zameranie je koncipované na základe Anholtovho hexagónu značky mesta. K prvkom značky mesta zarad'uje: prítomnost', miesto, predpoklady, l'udí, pulz a potenciál. Prítomnost' hovorí o medzinárodnom postavení, statuse mesta na globálnom trhu (príspevok k vede, kultúre a podiel na politickom vplyve) a znalosti mesta ciel’ovým publikom. Prvok značky územia - miesto predstavuje vnímanie fyzických vlastností mesta (klimatické podmienky, životné prostredie, atraktivita architektúry). Predpoklady definujú kvalitu miesta (infraštruktúra, cenová dostupnost', kvalita a dostupnost' verejných služieb, verejná doprava a pod.). Pulz zahŕňa vitalitu a energiu mestského života (podmienky pre trávenie vol'ného času, atrakcie, podujatia, zaujímavosti). L'udia vytvárajú obraz o meste, ide o ich správanie, reagovanie na situácie, ochotu pomôct' či poradit' - ich úlohou je vytvorit' také miesto, kde sa l’udia po ich boku budú cítit' bezpečne. Posledným prvkom Anholtovho Hexagónu značky mesta je potenciál, ktorý zahíňa ekonomické a študijné príležitosti (podnikanie, investovanie, univerzitné štúdium, pracovné príležitosti a pod).

Metodika hodnotenia značiek miest je založená na analýze percepcie atraktivity 50 miest sveta, ktoré sú hodnotené viac, ako pättisíc respondentami staršími ako 18 rokov, pochádzajúcimi z 10 krajín sveta (Austrália, Brazília, Č́na, Francúzsko, Nemecko, India, Rusko, Južná Kórea, USA a Vel'ká Británia), pričom každý z nich hodnotí 25 - 50 miest. Dopytovanie má charakter online rozhovorov v rodnom jazyku. Metodika vychádza z 24 kl'účových faktorov, ktoré považujú l’udia za najdôležitejšie pri výbere miesta na život, návštevu, podnikanie a investovanie. Zostavený súbor otázok prešiel testovaním validity $\mathrm{v}$ realizovanej online pilotáži. Ked’že v prieskume nie je možné dosiahnut' reprezentatívnu vzorku, bol použitý kvótny výber na báze základných socio - demografických váh - vek, pohlavie a dosiahnutá úroveň vzdelania (Ipsos, 2020).

The Resonance World's Best Cities od spoločnosti Resonance Consultancy hodnotí svetové metropoly a mestá s populáciou väčšou ako jeden milión obyvatel'ov. Celkovo je do rankingu The Resonance World's Best Cities zahrnutých 100 miest sveta. Pri každom zo skúmaných miest Resonance Consultancy hodnotí 24 faktorov, ktoré sú zoskupené do šiestich kategórií predstavujúcich konkurenčnú identitu mesta: miesto, program, prosperita, produkt, l’udia, propagácia. Miesto predstavuje vnímanú kvalitu prírodného a zastavaného prostredia mesta vrátane podkategórií: počasie, bezpečnost', pamiatky a architektúru. Výrobok zahŕňa kl'účové inštitúcie, atrakcie a infraštruktúru mesta vrátane podkategórií: prepojenie letísk, atrakcií, múzeí, univerzít, kongresových centier a športových klubov. Program obsahuje 
umenie, kultúru, zábavu a gastronómiu vrátane podkategórií: nákupy, reštaurácie a nočný život. Kategória - l'udia, zahíňa mieru prist'ahovalectva a rozmanitost' mesta vrátane dosiahnutého vzdelania a narodenia sa $\mathrm{v}$ zahraničí. Súčast'ou kategórie - prosperita sú spoločnosti a zamestnanost' vrátane podkategórií príjem domácností, miera zamestnanosti, rovnost' príjmu. Propagácia zahŕňa množstvo príbehov, referencií a odporúčaní zdiel’aných online o meste vrátane podkategórií: výsledky vyhl'adávania Google, Google Trends, prihlásení na Facebooku, hashtagov Instagramu a recenzií na TripAdvisor. Na hodnotenie značiek miest používa spoločnost' Resonance Consultancy sekundárne údaje o tradičných ukazovatel'och (napr. hrubý domáci produkt, priame zahraničné investície, zamestnanost', počet návštevníkov a i.), ktoré sú doplnené o analýzu percepcie značky mesta, prostredníctvom hodnotenia skúseností obyvatel’ov a návštevníkov mesta na sociálnych siet’ach (komentáre, obrázky, fotky, zdiel’ania s rodinou, priatel'mi a l'ud'mi na celom svete). Ciel'om rankingu The Resonance World's Best Cities je zistit', aké sú a kde sa nachádzajú jednotlivé mestá v porovnaní s konkurenciou, aké krátkodobé a dlhodobé investície by malo mesto urobit', aby sa zlepšila výkonnost' mesta, ako napreduje mesto $v$ priebehu času a aký majú vplyv jednotlivé marketingové stratégie a investície na rozvoj mesta

\section{Materiál a metódy skúmania}

Príspevok sa venuje aktuálnej téme úlohy potenciálu mesta pri budovaní jeho značky. Ciel’om príspevku je identifikovat' úlohu potenciálu mesta pri budovaní značky európskych a slovenských miest.

Našim základným predpokladom bolo tvrdenie spoločnosti Saffron Brand Consultants (2017), že mestá s lepším potenciálom, majú lepšiu východiskovú pozíciu pri budovaní značky, na základe ktorého testujeme hypotézu:

H0: Rozpoznatel'nost' mesta ako značky je vyššia pri mestách s lepším potenciálom.

Hypotézu sme overili výskumom na vzorke vybraných 14 európskych miest (Londýn, Paríž, Rím, Viedeň, Amsterdam, Barcelona, Mníchov, Berlín, Štokholm, Madrid, Dublin, Praha, Moskva, Istanbul), ktoré boli objektami rankingov Anholt - Ipsos City Brand Index a zároveň Resonace World Best Cities v roku 2020 a na všetkých 8 slovenských krajských mestách.

Pre identifikovanie úlohy potenciálu pri budovaní značky európskych miest sme použili výsledky rankingu Anholt - Ipsos City Brand Index a rankingu Resonace World Best Cities. Nakol'ko pre ranking Anholt - Ipsos City Brand Index, nie je vol'ne dostupné celkové bodové hodnotenie, ako aj bodové hodnotenie miest v jednotlivých kategóriách rankingu, mestám sme 
priradili body podl'a celkového umiestnenia mesta $\mathrm{v}$ rankingu. Rovnaký postup sme realizovali aj pri rankingu Resonace World Best Cities. Ako sme uviedli v časti 1.2 tohto článku, uvedené rankingy skúmajú rovnakých 24 faktorov, Anholt - Ipsos City Brand Index - z pohl'adu percepcie značky miest a Resonace World Best Cities - z pohl’adu potenciálu, ktorým mestá disponujú.

Nakol'ko ani jedno zo slovenských miest nie je objektom skúmania rankingov Anholt Ipsos City Brand Index a Resonace World Best Cities, sme pre identifikovanie úlohy potenciálu pri budovaní značky slovenských miest, vytvorili a následne použili vlastné rankingy hodnotiace značku a potenciál miest. Metodika rankingov slovenských miest vychádza z 24 faktorov definovaných firmou Ipsos (od roku 2018 používané aj v rankingoch Anholt - Ipsos City Brand Index a Resonace World Best Cities), ktoré sme pre hodnotenie značky mesta, ako aj potenciálu mierne prispôsobili a následne zaradili do 6 kategórií - status, produkt, kvalita, energia, príležitost', l'udia.

Status hovorí o politickom postavení mesta a jeho dôležitosti z pohl’adu prínosu k národnej kultúre, športu a vede. V hodnotení potenciálu mesta má svoje zastúpenie prostredníctvom ukazovatel'ov počtu inštitúcií verejnej správy s národným významom (napr. Úrad vlády SR, ministerstvá SR, Úrad priemyselného vlastníctva SR a i.), ukazovatel'ov počtu národných kultúrnych inštitúcií (napr. Slovenská národná galéria, Slovenské národné divadlo, Štátna vedecká knižnica a i.), ukazovatel’ov počtu vedecko - výskumných inštitúcií (vysoké školy, pobočky Slovenskej akadémie vied, výskumné centrá pre firmy a pod.) a ukazovatel'ov počtu športových zariadení a športovísk s možnost'ou využitia pre národné a medzinárodné podujatia. Produkt $\mathrm{v}$ tomto prípade predstavujú hmotné a nehmotné statky a charakteristiky mesta. $\mathrm{Z}$ pohl'adu hodnotenia potenciálu, produkt zahŕňa budovy, pamiatky, klimatické podmienky, parky a záhrady, nákupné centra a pod. Kvalita definuje mesto z pohl'adu dostupnosti poskytovaných verejných služieb, dopravy, bývania. Pre hodnotenie potenciálu v kategórií kvalita, sú zastúpené ukazovatele ako napr. počet zdravotníckych zariadení v rôznych kategóriách, počet zariadení sociálnych služieb, priemerná cena verejnej dopravy, dostupnost' vodnej, leteckej, železničnej dopravy, cena bytov, domov, pozemkov. Energia zahŕňa životaschopnost' mesta, napr. počet podujatí, atrakcie, zaujímavosti, aktivity a ponuku aktivít pre trávenie vol'ného času. Príležitost' definuje ekonomické a študijné možnosti mesta. Pri hodnotení sú pri kategórií - príležitost’, posudzované ukazovatele - počet vysokých a stredných odborných škôl, počet vol’ných pracovných miest, počet priemyselných parkov, počet podnikatel'ských a technologických inkubátorov, počet coworkingových centier, výška sadzby miestnych daní a poplatkov zameraných na podnikatel'ské subjekty a pod. L’udia 
prostredníctvom svojho správania, povahy, reči, výzoru definujú mesto, ako také. Z pohl’adu potenciálu je kategória l’udia zastúpená socio-demografickými ukazovatel’mi, hodnotením kvality pracovnej sily a údajmi o aktivitách, potrebách a správaní sa l’udí.

Skúmanie percepcie značky slovenských miest bolo realizované formou primárneho dotazníkového výskumu v období od 3. - 16. mája 2021. Obsahové zameranie dotazníka bolo koncipované na základe 24 faktorov zaradených do 6 kategórií. Dotazník obsahoval 24 uzatvorených otázok, s potrebou zoradenia odpovedí (miest) na základe subjektívnej preferencie respondenta a otázky zamerané na identifikáciu respondenta. Dotazník bol respondentom distribuovaný výlučne elektronicky. Výberovú vzorku tvorilo 100 obyvatel’ov SR nad 18 rokov, zloženie výberovej vzorky bolo reprezentatívne s ohl’adom na tri kvótne znaky - pohlavie, vek a príslušnost' ku kraju.

Skúmanie potenciálu slovenských miest bolo realizované expertnou analýzou ukazovatel'ov, reprezentujúcich 24 stanovených faktorov v 6 kategóriách. Údaje pre analýzu boli získané zo zdrojov: Štatistického úradu SR, Slovenského hydrometeorologického ústavu SR, Úradu práce sociálnych vecí a rodiny, Ministerstva vnútra SR, Ministerstva financií SR, Programov hospodárskeho rozvoja a sociálneho rozvoja jednotlivých miest, portálu TripAdvisor, portálu Booking.

Pri hodnotení značky a potenciálu miest sme každej zo 6 kategórií priradili rovnakú váhu a následne zostavili rankingy. Výsledky rankingov nám umožnili vypočítat’ mieru využívania potenciálu miest pri budovaní značky, danú ich podielom. Ďalej sme s využitím regresnej a korelačnej analýzy (na hladine významnosti $\alpha=0,05$ ), zist'ovali závislost' medzi potenciálom mesta a značkou mesta a identifikovali, ktoré zo 6 kategórií potenciálu mesta sa v najväčšej miere podiel’ajú na percepcií značky u súčasných, ako aj potenciálnych zákazníkov územia.

Na zadefinovanie vzt’ahu medzi budovaním značky mesta a potenciálom mesta používame metódu štúdia zahraničných a domácich vedeckých prác a odbornej literatúry.

\section{Výsledky a diskusia}

Niet pochýb o dôležitej úlohe potenciálu mesta pri budovaní jeho značky. S odvolaním sa na teoretický rámec príspevku, sme overili vzniknuté predpoklady na vzorke vybraných európskych a slovenských miest.

Ako ukazuje tabul'ka 1, podl'a l'udí z desiatich krajín sveta, ktorí sa zúčastnili prieskumu Anholt - Ipsos City Brands Index v roku 2020, je mesto Londýn vnímané, ako mesto s najlepšou značkou na svete. Na prvých desiatich priečkach rankingu sa umiestnili aj európske mestá: Paríž, Rím, Amsterdam a Viedeň. Európske mestá sa celkovo v rankingu Anholt - Ipsos City 
Brands Index umiestňujú na vel'mi vysokých priečkach a zvyčajne obsadzujú hornú polovicu rankingu.

Londýn sa umiestnil na prvom mieste aj v hodnotení potenciálu spoločnost'ou Resonance Consultancy. V prvej desiatke rankingu Resonace World Best Cities sa umiestnili aj európske mestá: Paríž, Barcelona a Moskva. Pomerne nízko ohodnotili l’udia značku mesta Moskva, aj napriek tomu, že podl'a hodnotenia Resonace World Best Cities disponuje silným potenciálom. Naopak značka mesta Viedeň je silne pozitívne vnímaná l'ud'mi, aj napriek tomu, že v hodnotení potenciálu sa umiestnila až na 39. mieste.

Najlepšie využívajú svoj potenciál na budovanie značky mestá: Štokholm, Viedeň, Mníchov, Dublin, Berlín, Rím, Praha a Amsterdam, ktorých značka je hodnotená lepšie, ako potenciál, čo však neznamená, že ich potenciál je nedostatočný. Priemerná miera využitia potenciálu pri budovaní značky európskych miest je $110 \%$.

Tabul'ka 1 Využitie potenciálu pri budovaní značky európskych miest

\begin{tabular}{|l|c|c|c|c|c|c|}
\hline \multirow{2}{*}{ Mesto } & \multicolumn{2}{c|}{ Značka } & \multicolumn{2}{c|}{ Potenciál } & \multicolumn{2}{c|}{$\begin{array}{c}\text { Využitie potenciálu } \\
\text { pri budovaní značky }\end{array}$} \\
\cline { 2 - 7 } & Poradie & Body & Poradie & Body & $\%$ & Poradie \\
\hline Londýn (GB) & 1 & 100,00 & 1 & 100,00 & $100 \%$ & 9 \\
\hline Paríž (FR) & 3 & 98,00 & 2 & 99,00 & $99 \%$ & 10 \\
\hline Rím (IT) & 5 & 96,00 & 14 & 87,00 & $110 \%$ & 6 \\
\hline Amsterdam (NL) & 6 & 95,00 & 12 & 89,00 & $107 \%$ & 8 \\
\hline Viedeň (AU) & 7 & 94,00 & 39 & 62,00 & $152 \%$ & 2 \\
\hline Berlín (DE) & 11 & 90,00 & 22 & 79,00 & $114 \%$ & 5 \\
\hline Barcelona (ES) & 12 & 89,00 & 5 & 96,00 & $93 \%$ & 11 \\
\hline Mníchov (DE) & 15 & 86,00 & 30 & 71,00 & $121 \%$ & 3 \\
\hline Štokholm (SE) & 17 & 84,00 & 48 & 53,00 & $158 \%$ & 1 \\
\hline Madrid (ES) & 21 & 80,00 & 12 & 89,00 & $90 \%$ & 13 \\
\hline Dublin (IE) & 22 & 79,00 & 33 & 68,00 & $116 \%$ & 4 \\
\hline Praha (CZ) & 23 & 78,00 & 29 & 72,00 & $108 \%$ & 7 \\
\hline Moskva (RU) & 31 & 70,00 & 6 & 95,00 & $74 \%$ & 14 \\
\hline Istanbul (TR) & 41 & 60,00 & 36 & 65,00 & $92 \%$ & 12 \\
\hline Mestá priemer & & 85,64 & & 80,36 & $110 \%$ & \\
\hline Zdroj: Vlastne spand
\end{tabular}

Zdroj: Vlastné spracovanie na základe poradia miest v rankingoch Anholt - Ipsos City Brands Index 2020 a Resonace World Best Cities 2020

Výsledky realizovanej regresnej analýzy potvrdili mierne silnú lineárnu závislost' medzi značkou a potenciálom európskych miest, čo naznačuje hodnota korelačného koeficientu 0,28. To znamená, že so zlepšujúcim sa potenciálom, rastie aj rozpoznatel’nost’ mesta ako značky. Hodnota spol'ahlivosti v tomto prípade dosiahla len 0,08 čo znamená, že zvolená regresná priamka vysvetl'uje variabilitu značky mesta len na $8 \%$. Znamená to, že silu značky mesta nie je možné vysvetlit' len potenciálom, ale až na 92 \% pôsobením iných, zatial' bližšie 
nešpecifikovaných faktorov. Vzt’ah medzi značkou a potenciálom európskych miest je zobrazený na bodovom grafe 1 .

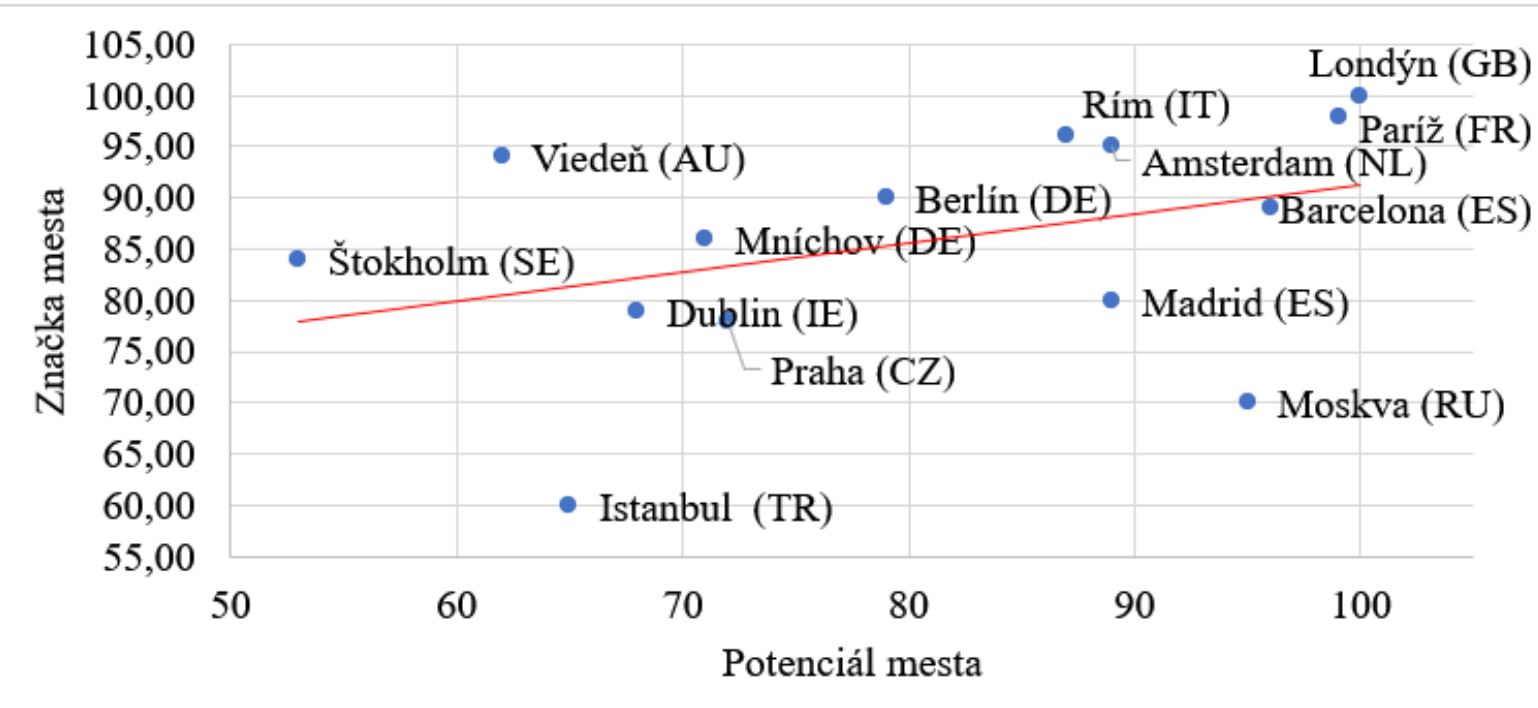

Graf 1 Využitie potenciálu pri budovaní značky európskych miest

Zdroj: Vlastné spracovanie na základe poriadia miest v rankingoch Anholt - Ipsos City Brands Index 2020 a Resonace World Best Cities 2020

Ako je možné vidiet' v tabul'ke 2, Slováci považujú mesto Košice za slovenské mesto $\mathrm{s}$ najlepšou značkou, na druhom mieste sa v celkovom hodnotení značky slovenských miest umiestnilo mesto Bratislava, nasledované Banskou Bystricou. S väčším bodovým rozdielom sa na d’alších priečkach umiestnili mestá Nitra, Prešov, Trenčín, Žilina a Trnava.

V hodnotení potenciálu sa podl'a našich predpokladov, na prvom mieste umiestnilo mesto Bratislava, nasledované Košicami. Banská Bystrica, ktorej značka bola hodnotená v rankingu hodnotiacom značky slovenských miest vel'mi dobre sa v hodnotení potenciálu, prekvapujúco, umiestnila až na šiestom mieste. Slovenské mesto s najslabšie hodnoteným potenciálom je mesto Trenčín.

V najväčšej miere využíva svoj potenciál pre budovanie značky mesto Banská Bystrica, nasledujú mestá Košice a Trenčín, ktorých miera využitia potenciálu pri budovaní značky je vyššia ako $100 \%$. Slovenské mesto s najlepším potenciálom - Bratislava využíva svoj potenciál pri budovaní značky len na $90 \%$. Mesto s najnižšou mierou využitia potenciálu pri budovaní značky je mesto Prešov, s mierou využitia potenciálu pri budovaní značky mesta na úrovni $51 \%$. Až pät' z ôsmych slovenských miest nedokáže pretavit' potenciál, ktorým disponuje do značky. Priemerná miera využitia potenciálu pri budovaní značky slovenských miest je na úrovni 94\%. 
Tabul'ka 2 Výsledky rankingu hodnotiaceho značku a potenciál slovenských miest

\begin{tabular}{|c|c|c|c|c|c|c|}
\hline \multirow{2}{*}{ Mesto } & \multicolumn{2}{|c|}{ Značka } & \multicolumn{2}{c|}{ Potenciál } & \multicolumn{2}{c|}{$\begin{array}{c}\text { Využitie potenciálu } \\
\text { pri budovanie značky }\end{array}$} \\
\cline { 2 - 7 } & Poradie & Body & Poradie & Body & $\%$ & Poradie \\
\hline Banská Bystrica & 3 & 75,39 & 6 & 54,35 & $139 \%$ & 1 \\
\hline Košice & 1 & 81,79 & 2 & 73,56 & $111 \%$ & 2 \\
\hline Trenčín & 6 & 49,48 & 8 & 45,23 & $109 \%$ & 3 \\
\hline Nitra & 4 & 60,05 & 3 & 65,51 & $92 \%$ & 4 \\
\hline Bratislava & 2 & 77,87 & 1 & 86,85 & $90 \%$ & 5 \\
\hline Žilina & 7 & 42,19 & 5 & 57,8 & $73 \%$ & 6 \\
\hline Trnava & 8 & 25,37 & 7 & 48,96 & $52 \%$ & 7 \\
\hline Prešov & 5 & 51,08 & 4 & 58,77 & $51 \%$ & 8 \\
\hline Mestá priemer & & 57,90 & & 61,38 & $94 \%$ & \\
\hline
\end{tabular}

Zdroj: Vlastné spracovanie, 2021

Výsledky realizovanej regresnej analýzy s hodnotou korelačného koeficientu na úrovni 0,84, potvrdili vel’mi silnú priamu lineárnu závislost' medzi značkou a potenciálom slovenských miest. To znamená, že čím je potenciál mesta lepší, tým silnejšia je aj rozpoznatel’nost' mesta ako značky. Zvolená regresná priamka vysvetluje variabilitu značky mesta na 70,97 \%, ostatná čast' predstavuje nevysvetlenú variabilitu, vplyv náhodných činitel'ov a iných v súčasnej dobe bližšie nešpecifikovaných vplyvov. Vzt'ah značky a potenciálu slovenských miest je zobrazený aj na bodovom grafe 2 .

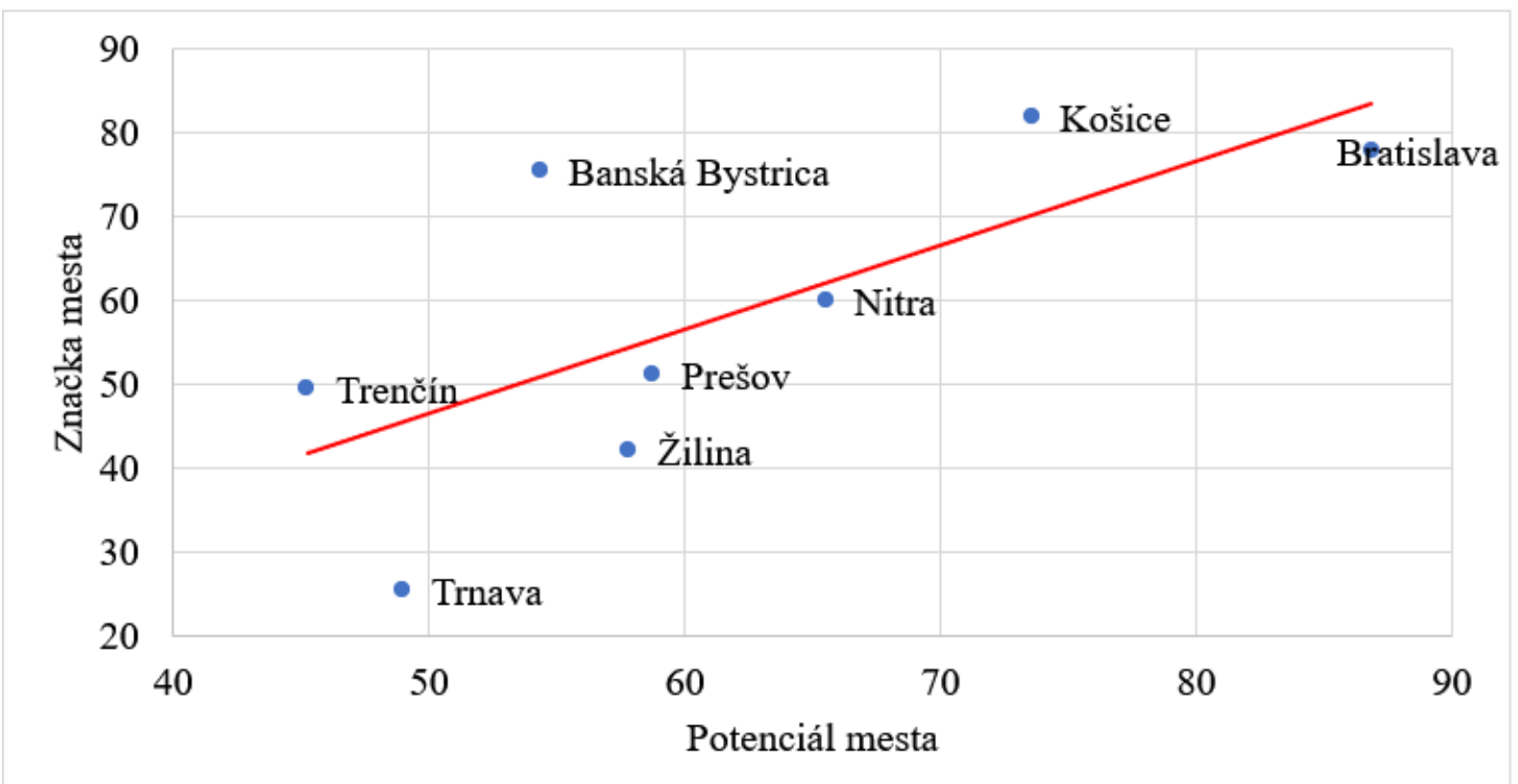

Graf 2 Využitie potenciálu pri budovaní značky slovenských miest

Zdroj: Vlastné spracovanie, 2021 
Napriek tomu, že sa mesto Bratislava neumiestnilo na predpokladanej prvej priečke v celkovom hodnotení značiek slovenských miest, pomerne silne má hodnotené kategórie status, energia a príležitost'. Slabšie hodnotenie značky získalo mesto Bratislava v kategóriách prvkov produkt, kvalita a l'udia. Hodnotenie potenciálu bolo pomerne vysoké a vyrovnané vo všetkých kategóriách, čo sme predpokladali, vzhl’adom na fakt, že mesto Bratislava je hlavným mestom SR. Výsledky hodnotenia potenciálu a značky mesta Bratislava zobrazuje graf 3.

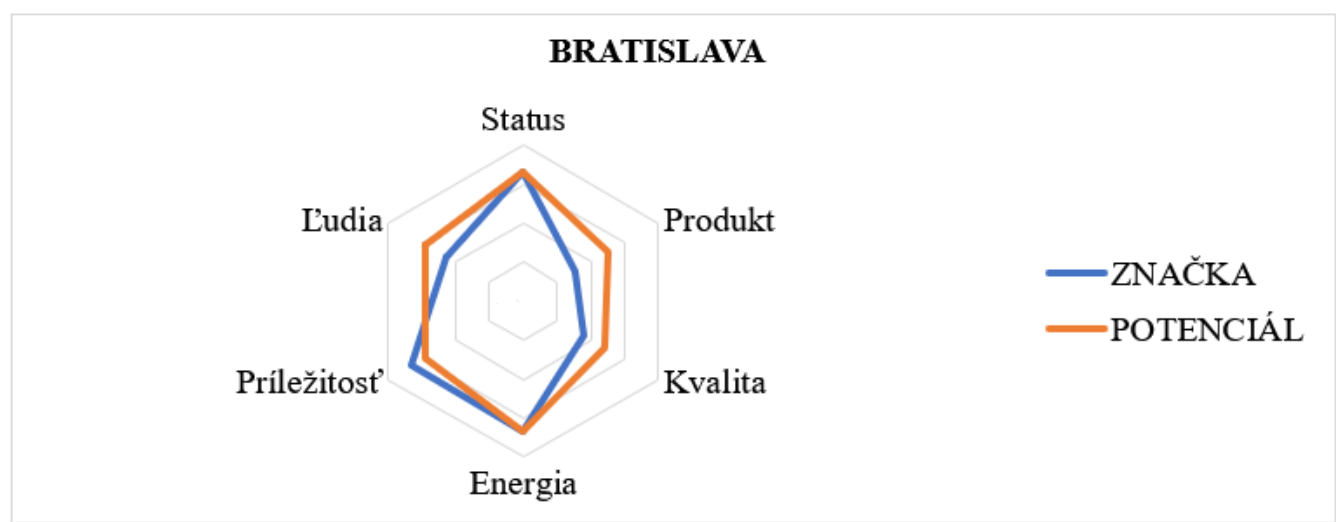

Graf 3 Radarová mapa potenciálu a značky mesta Bratislava Zdroj: Vlastné spracovanie, 2021

Ako je možné vidiet' na grafe 4, značka mesta Košice je pomerne vyrovnane hodnotená vo všetkých kategóriách prvkov. Nižšie hodnotenie značky získalo mesto Košice v kategórií kvalita, ktorá zahŕňa najmä vnímanie dostupnosti a kvality verejných služieb, dopravy a bývania. Hodnotenie potenciálu mesta Košice bolo slabšie aj v kategóriách produkt a príležitost'.

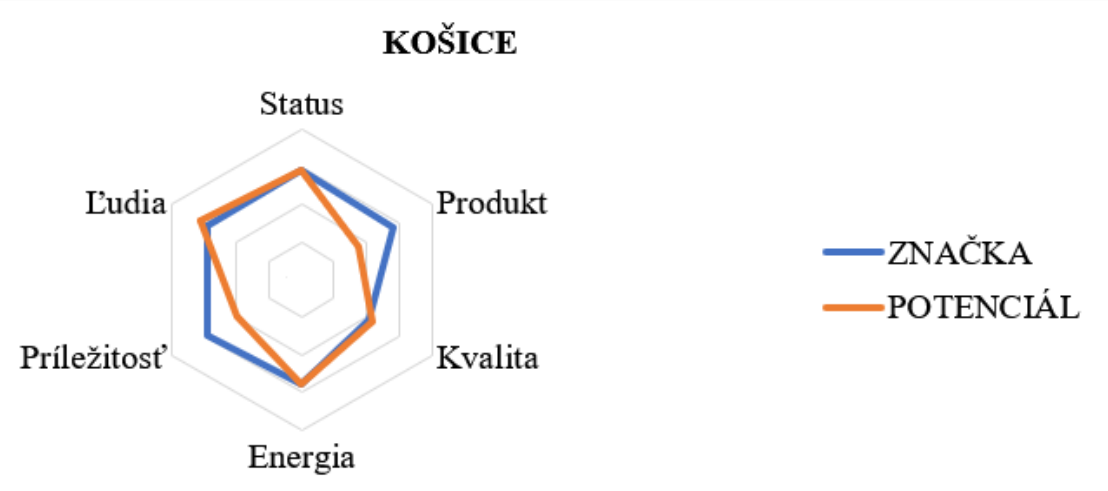

Graf 4 Radarová mapa potenciálu a značky mesta Košice

Zdroj: Vlastné spracovanie, 2021

Značka mesta Banská Bystrica bola respondentmi, pozitívne hodnotená vo všetkých kategóriách prvkov. Najlepšie hodnotenie značky získala Banská Bystrica v kategórií produkt, za prvky - prírodné prostredie, architektúru a celkový vzhl’ad mesta. Mesto Banská Bystrica má 
slabšie hodnotený ekonomický potenciál v rámci kategórie príležitost'. Hodnotenie potenciálu a značky mesta Banská Bystrica zobrazuje graf 5.

\section{BANSKÁ BYSTRICA}

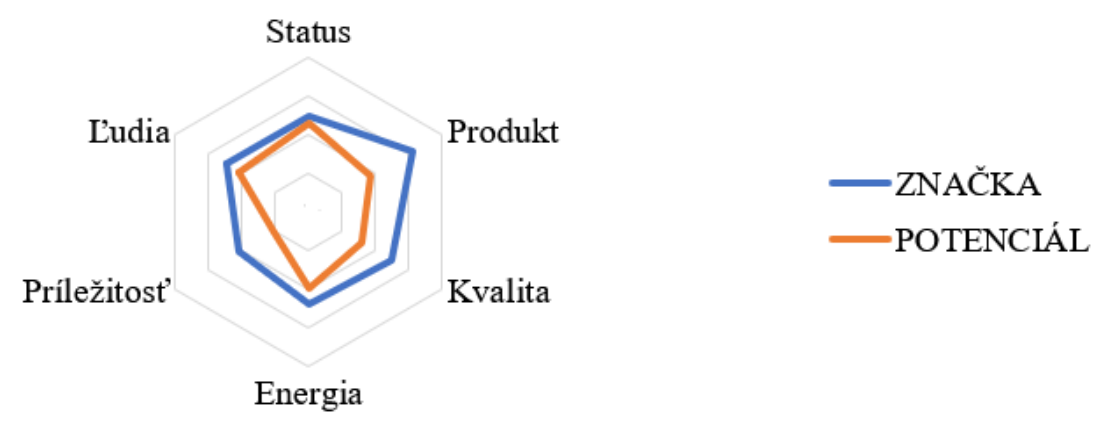

Graf 5 Radarová mapa potenciálu a značky mesta Banská Bystrica Zdroj: Vlastné spracovanie, 2021

Pri meste Prešov boli zistené najväčšie rozdiely medzi hodnotením značky a potenciálu v kategóriách l’udia a príležitost' (graf 6). Aj napriek tomu, že ekonomický a študijný potenciál mesta Prešov bol hodnotený pomerne vysoko, l’udia vnímajú mesto Prešov ako mesto s malou ponukou ekonomických a študijných príležitostí. Vel'mi vysoko bol hodnotený l'udský potenciál, čo je dané najmä ponukou pracovnej sily a pomerne pozitívnym sociodemografickým vývojom v porovnaní s ostatnými mestami SR.

\section{PREŠOV}

Status

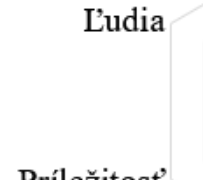

Príležitost'

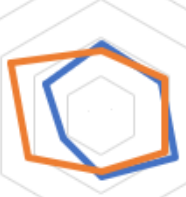

Energia
Produkt

ZZNAČKA

-POTENCIÁL

Kvalita

Graf 6 Radarová mapa potenciálu a značky mesta Prešov

Zdroj: Vlastné spracovanie, 2021

Graf 7 ukazuje, že hodnotenie značky mesta Nitra je rovnomerné v každej zo skúmaných kategórií prvkov. Napriek tomu, mesto Nitra vyniká hodnotením potenciálu v kategóriách produkt a l'udia. Vysoké hodnotenie potenciálu mesta Nitra v kategórií produkt súvisí najmä s počtom a rozlohou zelených plôch a počtom pamiatok. Nízke skóre mesta Nitra v hodnotení l’udského potenciálu je dané najmä nepriaznivým demografickým vývojom 


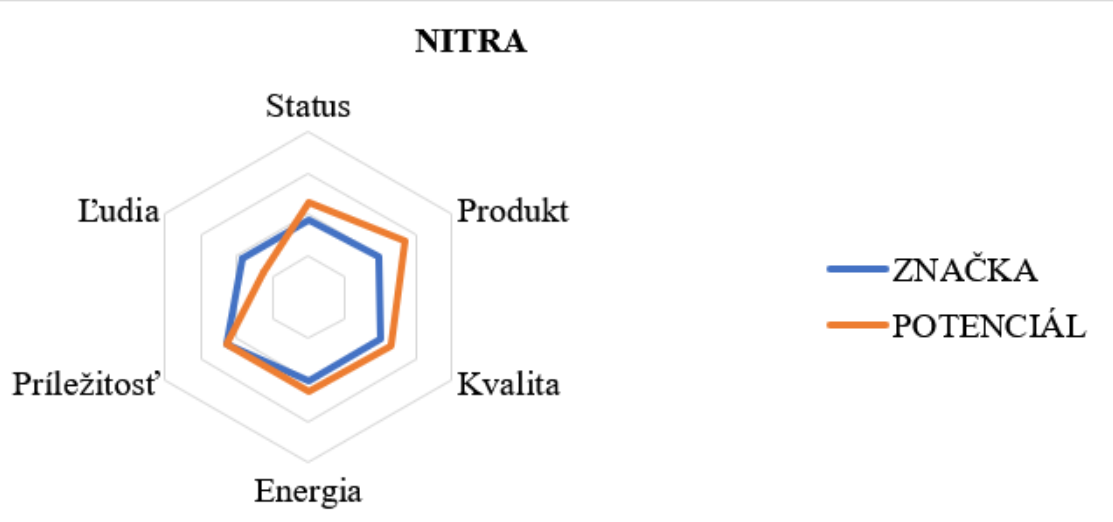

Graf 7 Radarová mapa potenciálu a značky mesta Nitra Zdroj: Vlastné spracovanie, 2021

Značka mesta Žilina bola hodnotená vel'mi nízko vo všetkých šiestich skúmaných kategóriách prvkov, čo je možné vidiet’ na grafe 8 . Najhoršie hodnotili respondenti Žilinu z pohl’adu jej prínosu k vede, kultúre a športu na národnej úrovni. Nižšie hodnotenie potenciálu získalo mesto Žilina v kategóriách príležitost' a kvalita.

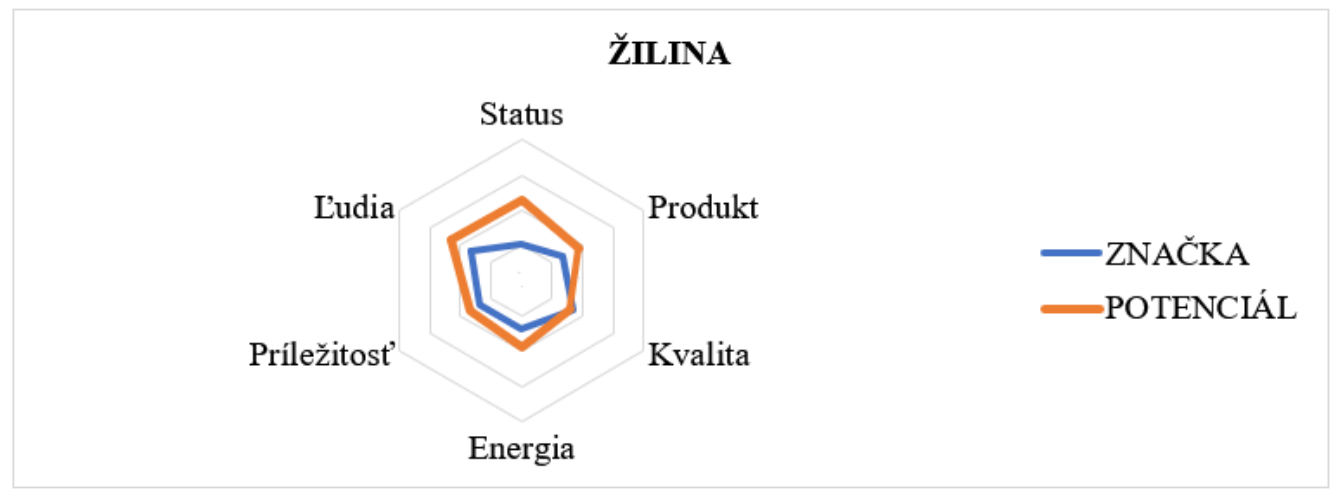

Graf 8 Radarová mapa potenciálu a značky mesta Žilina

Zdroj: Vlastné spracovanie, 2021

Výsledky hodnotenia potenciálu a značky mesta Trenčín sú nízke vo všetkých šiestich kategóriách. Vyššie hodnotenie získala značka mesta Trenčín v kategórií l’udia, napriek tomu, že hodnotenie potenciálu v tejto kategórií bolo vel'mi nízke. Respondenti pomerne pozitívne vnímajú mesto Trenčín z pohl'adu možností pre trávenie vol’ného času, zábavu a oddych. Hodnotenie potenciálu, však naznačuje, že oproti ostatným skúmaným slovenským mestám, má mesto Trenčín najhoršie podmienky pre vol'nočasové aktivity. Hodnotenie jednotlivých kategórií potenciálu a značky mesta Trenčín, zobrazuje graf 9. 


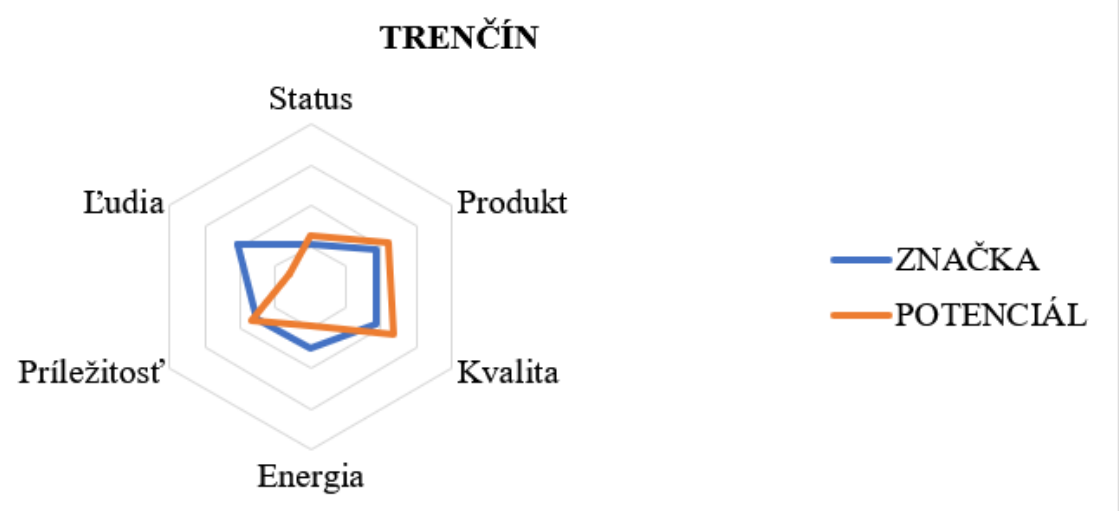

Graf 9 Radarová mapa potenciálu a značky mesta Trenčín

Zdroj: Vlastné spracovanie, 2021

Trnava sa umiestnila na poslednom mieste $\mathrm{v}$ rankingu hodnotiacom značky slovenských miest, čo naznačuje aj vel'mi slabé hodnotenie značky mesta, respondentami, vo všetkých šiestich skúmaných kategóriách prvkov. Pomerne nízko bol hodnotený aj potenciál mesta Trnava. Lepšie bol ohodnotený len potenciál v oblasti poskytovania verejných služieb a dostupnosti bývania (graf 10).

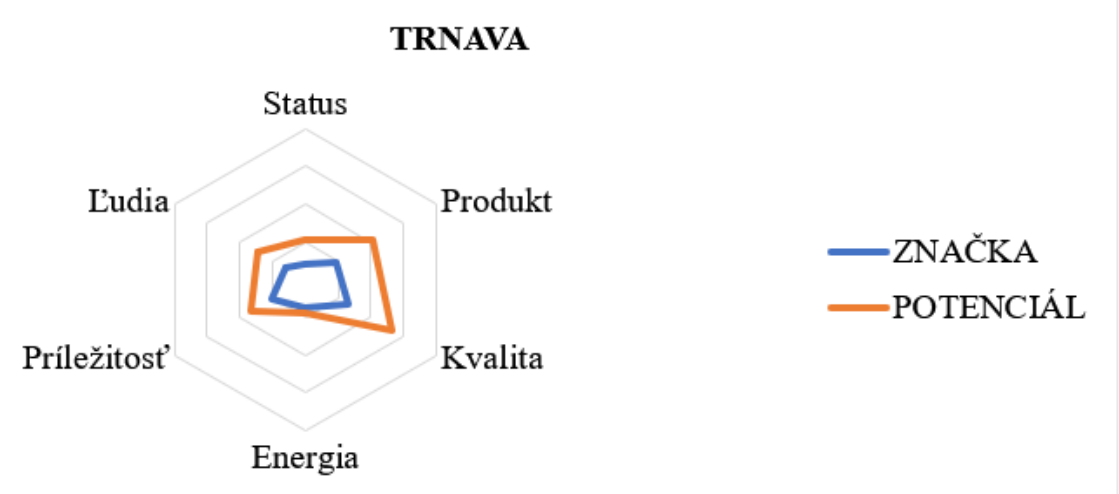

Graf 10 Radarová mapa potenciálu a značky mesta Trnava

Zdroj: Vlastné spracovanie, 2021

Ďalej sme prostredníctvom korelačnej analýzy zist’ovali vzájomnú závislost’ značky mesta a jednotlivých kategórií prvkov potenciálu mesta. Z výsledkov realizovanej korelačnej analýzy (tabul'ka 3) je zrejmé, že medzi jednotlivými kategóriami prvkov potenciálu mesta a značky mesta je mierna až silná priama lineárna závislost'. V najväčšej miere ovplyvňuje percepciu značky slovenských miest kategória energia, s korelačným koeficientom 0,7669, ktorá definuje životaschopnost' mesta, napr. podujatia, atrakcie, zaujímavosti, aktivity a ponuka aktivít pre trávenie vol'ného času. Vel'mi silný vplyv na percepciu značky slovenských miest má tiež kategória status, ktorá zahŕn̆a postavenie mesta na národnej úrovni v oblasti vedy, kultúry a športu, ako aj kategórie príležitosti a l'udia, ktoré definujú mesto z pohl'adu ekonomických 
a študijných povinností a l'udí. V najmenšej miere vplývajú na percepciu značky kategórie produkt a kvalita.

Tabul'ka 3 Vzt’ah medzi značkou mesta a jednotlivými kategóriami potenciálu mesta

\begin{tabular}{|l|r|}
\hline \multicolumn{1}{|c|}{ Kategória } & Značka mesta (korelačný koeficient) \\
\hline Status & 0,6870 \\
\hline Produkt & 0,2906 \\
\hline Kvalita & 0,2056 \\
\hline Energia & 0,7669 \\
\hline Príležitosti & 0,6293 \\
\hline Ludia & 0,5999 \\
\hline
\end{tabular}

Zdroj: Vlastné spracovanie

\section{Záver}

Hlavnou myšlienkou článku bolo identifikovat’ úlohu a mieru využívania potenciálu pri budovaní značky vybraných európskych a slovenských miest. Výsledky realizovanej regresnej analýzy dokázali, že medzi značkou mesta a potenciálom mesta je priama lineárna závislost'. To znamená, že čím je potenciál mesta lepší, tým silnejšia je aj rozpoznatel'nost' mesta ako značky. Mestá, ktoré disponujú silným potenciálom, ako napr. Londýn, Paríž, Barcelona, Amsterdam, Košice, Bratislava majú prirodzene lepšiu východiskovú pozíciu pri budovaní značky. Niektoré prvky potenciálu mesta (identifikované realizovanou korelačnou analýzou), ako napr. pulzujúca kultúrna scéna, zaujímavosti, atrakcie, postavenie mesta v oblasti kultúry, športu alebo vedy na národnej úrovni, možnosti pre štúdium alebo zamestnanie, majú tendenciu automaticky udelit' silu ich značke a zvýšit' tak rozpoznatel'nost' mesta ako značky. Naopak mestá s nízkou hodnotou potenciálu, ako Istanbul, Trnava, Prešov, Žilina majú aj nízke hodnotenie značky.

Zaujímavým zistením však je, že až 5 zo 14 európskych miest a 5 z 8 slovenských miest nevyužívajú pri budovaní značky mesta, naplno potenciál, ktorým disponujú, čo dokazuje miera využívania potenciálu pri budovaní značky, menšia ako 100 \%. Podl'a nášho názoru, práve v situáciách, ked' má mesto silný potenciál, avšak jeho využitie je nedostatočné, mal by manažment mesta zvážit' využitie vhodných foriem a nástrojov marketingovej komunikácie pre zvýšenie percepcie vybraných prvkov značky mesta, tak u súčasných, ako aj potenciálnych spotrebitel'ov územia.

Výsledky realizovanej analýzy potvrdzujú predpoklad H0, že rozpoznatel'nost' mesta ako značky je vyššia pri mestách s lepším potenciálom. Je potrebné si tiež však uvedomit', že napriek tomu, že potenciál mesta zohráva dôležitú úlohu pri budovaní značky, nakol'ko ovplyvňuje rozpoznatel'nost' mesta ako značky, nie je jediným faktorom, ktorý ju ovplyvňuje. 
Dôležitú úlohu zohráva aj marketingová komunikácia a samotný spôsob, akým je značka mesta budovaná..

Grantová podpora: Príspevok je výstupom riešeného projektu APVV SK-FR-19-0009 Financovanie politiky kultúry a kreatívnych odvetví. Francúzsko slovenské porovnanie a projektu VEGA 1/0213/20 Smart Governance v podmienkach miestnej samosprávy.

\section{Zoznam použitej literatúry}

[1] Anholt, S. (2007a). Competitive Identity: The New Brand Management for Nations, Cities and Regions. [Konkurenčná identita: Nový manažment značky pre národy, mestá a regióny]. London, UK: Palgrave Macmillan.

[2] Anholt, S. (2007b). Place branding: Is it marketing, or isn't it? [Budovanie značky územia: Je to marketing, alebo nie?]. Place branding and public diplomacy, 4(1), 1-6. doi: 10.1057/palgrave.pb.6000088

[3] Anholt, S. (2014). Place Branding Research. Taking Your Reputation Places. [Výskum budovania značky územia. Zaujímajte sa o reputáciu svojich miest]. GfK

[4] Ashworth G. J. et al. (2015). The Need to Rethink Place Branding [Potreba prehodnotit' značku územia]. In: Kavaratzis M., Warnaby G., Ashworth G. (Eds) Rethinking Place Branding (pp. 1-11). Switzerland: Springer.

[5] Baker, B. (2019). Place Branding for Small Cities, Regions and Downtowns: The Essentials for Successful Destinations. [Budovanie značky územia pre malé mestá, regióny a mestečká: Základy dosahovania ciel'ov]. London, GB: Independently published.

[6] Beerli, A. M., \& Josefa, D. (2004). Factors influencing destination image. [Faktory ovplyvňujúce imidž destinácie]. Annuals of Tourism Research 31(3), (657 - 681). doi: 10.1016/j.annals.2004.01.010.

[7] Braun, E. et al. (2014). The effectiveness of place brand communication. [Efektívna komunikácia značky územia]. Cities 41, 64-70. doi: 10.1016/j.cities.2014.05.007.

[8] Cavia, J. F., et al. (2018). Place branding: A communication perspective. [Budovanie značky územia: Komunikačná perpektíva]. Communication and society, 31(4), 1-7. doi: 10.15581/003.31.4.1-6.

[9] Dinnie, K. (2009). Nation Branding: Concepts, Issues, Practice. [Budovanie značky národa: Koncept, problémy, prax]. Amsterdam, NL: Elsevier. 
[10]Eshuis, J., et al. (2014). Place marketing and citizen participation: branding as strategy to address the emotional dimension of policy making? [Marketing a účast' občanov: značka ako stratégia na riešenie emocionálneho rozmeru tvorby politiky]. International Review of Administrative Sciences, 80(1), 151-171. doi: 10.1177/0020852313513872.

[11]Florek, M. (2011). No place like home: perspective on place attachment and impacts on the city management [Žiadne miesto ako doma: pohl'ad na pripevnenie miesta a dopady na správu mesta]. Journal of Town and City Management, 1(4), 346-354.

[12]Foret, M. (2006). Marketingová komunikace. Brno, CZ: Computer Press.

[13]Frantál, B. (2007). Územní identita, image a place branding: nové perspektívy a strategie rozvoje měst a regionu v dobe globalizace, Sborník př́spevku zX. medzinárodního kolokvia o regionálních vědách. Brno: Masarykova univerzita.

[14] Govers, R., Go. F. (2009). Place Branding: Glocal, Virtual and Physical Identities, Constructed, Imagiden and Experiences. Basinstone, GB: Palgrave Macmillan.

[15]Chromý, P. et al. (2014). Regionální vědomí a regionální identikta v Česku: případová studie Českého ráje. Geografie, 119(3), 259-277.

[16]Ipsos. (2020). Anholt - Ipsos City Brand Index 2020. Tlačová správa, New York, NY: Anholt, S.

[17] Kavaratzis, M. (2008). From city marketing to city branding: an interdisciplinary analysis with reference to Amsterdam, Budapest and Athens. s.n. [Od marketingu mesta po budovanie značky mesta: interdisciplinárna analýza s odkazom na Amsterdam, Budapešt’ a Atény]. Dostupné na https://pure.rug.nl/ws/portalfiles/portal/33151132/04-c3.pdf .

[18] Kavaratzis, M. (2010). Is corporate branding relevant to places? [Je podniková značka porovnatel'ná s mestskou? ]. In Ashworth, G., Kavaratzis, M. 2010. Towards effective place brand management: Branding European cities and regions [ $\mathrm{Na}$ ceste $\mathrm{k}$ efektívnemu riadeniu značky: Branding európskych miest a regiónov] (pp. 36-48). Cheltenham, UK: Edward Elgar Pub.

[19] Kerr, G., \& Oliver, J. (2015). Rethinking Place Identities. [Prehodnotenie identít miest]. In M. Kavaratzis, G. Warnaby, \& G. Ashworth (Eds.), Rethinking Place Branding: Comprehensive Brand Development for Cities and Regions [Znovu premyslenie značky: Komplexný rozvoj značky pre mestá a regióny], (pp. 61-72). Switzerland: Springer International Publishing.

[20] Kotler, P. et al. (1993). Marketing places. [Marketing miest]. New York, NY: Free Press. [21] Matlovičová, K. (2015). Značka územia. Prešov, SK: Grafotlač. 
[22] Mueller, A., \& Schade, M. (2012). Symbols and place identity, a semiotic approach to internal place branding - case study Bremen (Germany). [Symboly a identita územia, semiotický prístup k internému značeniu miest - prípadová štúdia Brémy (Nemecko)]. Journal of Place Management and Development, 5(1), 81-92. doi: $10.1108 / 17538331211209068$

[23] Resonance Consultancy. (2020). Resonance World Best Cities 2020 (Tlačová správa). Dostupné na internete: https://www.bestcities.org/rankings/worlds-best-cities/

[24]Rojíková, D. (2021). Budovanie značky územia a moderné formy marketingovej komunikácie (Písomná práca na dizertačnú skúšku). Ekonomická fakulta Univerzity Mateja Bela.

[25] Saffron Brand Consultants. (2017). The Saffron European City Brand Barometer. Revealing which cities get the brands they deserve. [Európsky barometer značky mesta. Odhalenie, ktoré mestá dostanú značky, aké si zaslúžia]. London, UK: Hildreth, J.

[26] Siwek, T. (2011). Percepce geografického prostoru. Praha, CZ: Česká geografická spoločnost'.

[27] Tapachai, N., \& Waryszak, R. (2000). An Examination of the Role of Beneficial Image in Tourism Destination Selection. [Preskúmanie úlohy prospešného imidžu pri výbere destinácie cestovného ruchu]. Journal of Travel Research, 39, 37-44. doi: $10.1177 / 004728750003900105$.

[28] Vaňová, A. (2006) Strategické marketingové plánovanie rozvoja územia. Banská Bystrica, SK: Ekonomická fakulta UMB.

[29] Vaňová, A. et al. (2017). Marketing územia. Banská Bystrica, SK: Belianum.

[30] Vela, J. S. E. (2013). Place branding: A conceptual and theoretical framework. [Budovanie značky územia: Konceptuálny a teoretický rámec]. Boletín de la Asociación de Geógrafos Españoles, 62, 467-471.

[31]Zenker, S. (2011). How to catch a city? The concept and measurement of place brands. [Ako chytit' mesto? Koncept a meranie značiek území]. Journal of Place Management and Development, 4(1), 40-52. doi: 10.1108/17538331111117151

Adresa autorov: Bc. Jana Matejčíková, Ing. Darina Rojíková. Ekonomická fakulta Univerzity Mateja Bela, Tajovského 10, 97590 Banská Bystrica; e-mail: jana.matejcikova@student.umb.sk,darina.rojikova@umb.sk 